\title{
Bilineal acute leukemia: a rare expression of common ALL markers and pre-T markers
}

\author{
Leucemia aguda bilineal: marcadores e pre T marcadores, uma rara expressão na leucemia aguda \\ linfoblástica comum
}

Fernando Callera

\begin{abstract}
In this case report the case of bilineal acute leukemia with a rare expression of common ALL and pre-T markers is presented. The cytogenetic and immunophenotypic clinical aspects of a 38-year-old male patient are described.
\end{abstract}

Key words: Acute lymphoblastic leukemia; cytogenetics; immunophenotyping.

\section{Introduction}

The composite phenotype of a population of leukemic blast cells is derived through analysis of the morphology, cytochemistry, cytogenetics, surface antigens and more recently, gene structure. ${ }^{1,2}$ When analyzed in such a fashion, bilineal acute leukemia accounts for less than 4 percent of all cases of acute leukemia. ${ }^{3}$ In the present study we described an unusual case of bilineal adult acute leukemia with two immunologically distinct blast cell subsets expressing common ALL markers and pre-T markers.

\section{Case report}

A 38-year-old man was referred to our facility with anemia and thrombocytopenia. He stated that he had recently had recurrent fever $\left(38^{\circ} \mathrm{C}\right.$ to $\left.38.5^{\circ} \mathrm{C}\right)$, fatigue, loss of appetite and weight loss. He was asymptomatic until three weeks before admission in our facility. On physical examination, the patient was afebrile. Petechiae were present all over the legs. The head, neck, lungs, abdomen, and arms and legs were normal, and the results of a neurologic examination showed no abnormalities. Blood levels of aminotransferases (AST and ALT), alkaline phosphatase, gamma-glutamyl transpeptidase, bilirubin, blood urea nitrogen, creatinine, glucose and serum LDH were normal. The white-cell count was $1,500 / \mathrm{mm}^{3}$ with 26 percent circulating blasts. Hemoglobin level was $4.5 \mathrm{~g} / \mathrm{dL}$ and platelet count was $31,000 / \mathrm{mm}^{3}$. The bone marrow aspirate was reported to show a hypercellular marrow with 100 percent blast cells with high nuclear/cytoplasm ratio, basophilic cytoplasm and non-condensed nuclear chromatin. On a peroxidase stain the blasts showed fine granular positivity (18 percent); periodic acid-Schiff positivity was observed in 3 percent of the blasts (Figure 1). Immunophenotyping of a bone marrow aspirate by flow cytometry revealed two immunologically distinct blast cell subsets expressing common ALL markers (TdT, CD19+, CD22+, CD10+) and pre-T markers (cCD3+, CD5+, CD7+, CD1a-, CD2-, mCD3-, CD4-, CD8-) respectively (Table 1). Cytogenetic studies performed from bone marrow in short-term unstimulated culture did not evidence abnormalities $(46, \mathrm{XY})$. These findings defined the diagnosis of bilineal acute leukemia.

The patient received a five-drug remission induction regimen with intensive consolidation for adult acute lymphoblastic leukemia (Cancer and Leukemia Group B

\begin{tabular}{lcc}
\multicolumn{2}{c}{$\begin{array}{c}\text { Table 1 } \\
\text { Immunophenotypic characteristics of blast cells }\end{array}$} \\
\hline & \multicolumn{2}{c}{ Blast cells } \\
\hline B-lineage $(50 \%)$ & T-lineage (50\%) \\
\hline Positive markers & $\begin{array}{c}\text { CD10, CD19, CD22, } \\
\text { CD79a, clgM, TdT }\end{array}$ & $\begin{array}{c}\text { cCD3, CD5, CD7, } \\
\text { CD34, TdT }\end{array}$ \\
Negative markers & CD34 & HLA-DR, CD1a, CD2, mCD3, CD4, CD8
\end{tabular}

Serviço de Hematologia e Hemoterapia de São José dos Campos-SP.

Correspondence: Fernando Callera

Serviço de Hematologia e Hemoterapia de São José dos Campos

Rua Antonio Sais, 425 - Centro

12210-040 - São José dos Campos-SP - Brasil

Tel/Fax: 551239213766 -e-mail:fcallera@shhsjc.com.br - Site: www.shhsjc.com.br 

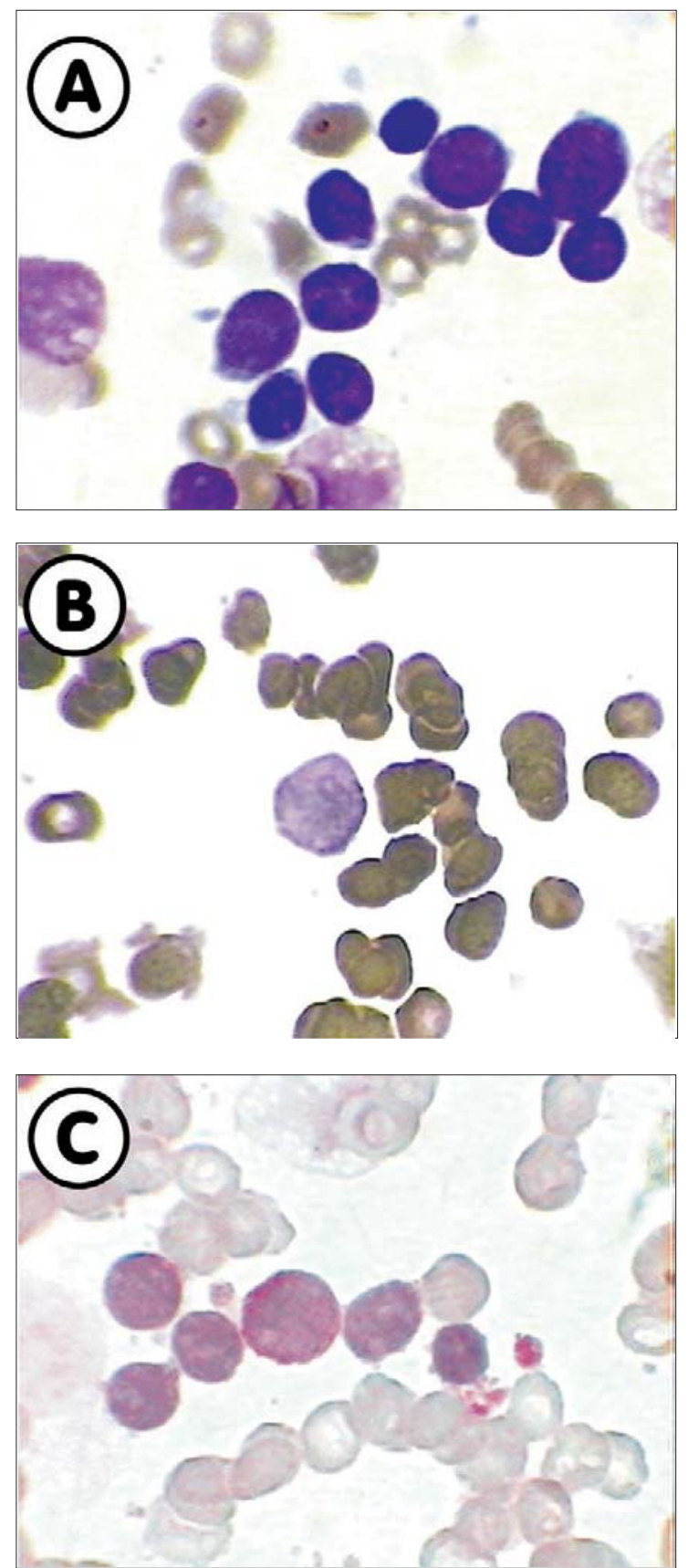

Figure 1. Bone marrow films showing blast cells $(A)$ stained by peroxidase (B) and periodic acid-Schiff (C)

Study 8811). ${ }^{4}$ One month after his initial treatment, bone marrow aspiration was performed, and the aspirate showed a hypocellular marrow without leukemic cells - features suggestive of cellular remission. The patient has been seen as an outpatient at this facility.

\section{Discussion}

We made a literature review on immunophenotypic markers in bilineal acute leukemia from 1980 to the second quarter of $2004 .{ }^{5}$ Some specific bilineal acute leukemia syndromes have been identified; among them are acute nonlymphoid leukemia with T-lymphoid features, CD7+, CD4-, CD8- acute leukemia, CD2+/CD19+ acute lymphoid leukemia, and acute leukemias associated with specific cytogenetic markers, e.g., $\mathrm{t}(4 ; 11)$ and $\mathrm{t}(9 ; 22){ }^{6,7}$ However, the occurrence of bilineal acute leukemia of common ALL markers and pre-T markers has not been described.

\section{Conclusion}

Given the paucity of analyses in this field, the clinical consequences as well as the influence on the disease outcome resulting from the occurrence of aberrant markers in patients with bilineal acute leukemias remain unresolved. We therefore believe that reports from centers and health facilities regarding different aspects of this intriguing disease should be stimulated.

\section{Resumo}

Neste relato é apresentado um caso de LA bilineal, com expressão rara de marcadores da LLA comum e pré T, sendo descritos os aspectos clínicos citogenéticos e imunofenotípicos de um paciente masculino com 38 anos de idade. Rev. bras. hematol. hemoter. 2005;27(1):70-71.

Palavras-chave: Leucemia linfóide aguda; citogenética; imunofenotipagem.

\section{References}

1. Stasi R, Del Poeta G, Venditti A, et al. Lineage identification of acute leukemias: relevance of immunologic and ultrastructural techniques. Hematol Pathol 1995;9(2):79-94.

2. Pui CH, Relling MV, Downing JR. Mechanisms of disease: Acute Lymphoblastic Leukemia. N Engl J Med 2004;350(15):1535-48.

3. WHO Classification of Tumours of Haematopoietic and Lymphoid Tissues. In: Jaffe ES, Harris NL, Stein H, Vardiman JW, eds. Lyon: International Agency for Research on Cancer Press, 2001:106-7.

4. National Center for Biotechnology Information. Available from http://www.ncbi.nlm.nih.gov/pubmed.

5. Larson RA, Dodge RK, Burns CP et al. A five-drug remission induction regimen with intensive consolidation for adults with acute lymphoblastic leukemia: Cancer and Leukemia Group B Study 8811 1995;85(8):2025-37.

6. Zomas AP, Swansbury GJ, Matutes E et al. Bilineal acute leukemia of $\mathrm{B}$ and $\mathrm{T}$ lineage with a novel translocation $\mathrm{t}(9 ; 17)(\mathrm{p} 11 ; \mathrm{q} 11)$. Leuk Lymphoma 1997;25(1-2):179-85.

7. Altman AJ. Clinical features and biological implications of acute mixed lineage (hybrid) leukemias. Am J Pediatr Hematol Oncol 1990;12(2):123-33.

Avaliação: Editor e dois revisores externos.

Conflito de interesse: não declarado

Recebido: 02/01/04

Aceito após modificações: 07/03/05 